\title{
Physicochemical properties of edible cricket (Gryllus bimaculatus) in different districts
}

\author{
Eun-Mi Kim ${ }^{1}$, Dae-Hyun Kim${ }^{1}$, Jeong-Ho Lim ${ }^{1 *}$, Yoon-Je Chang ${ }^{1}$, Yong-Hwan Lee ${ }^{1}$, \\ Jin Ju Park ${ }^{1}$, Mi-Young $\mathrm{Ahn}^{2}$ \\ ${ }^{1}$ Korea Food Research Institute, Seongnam 13539, Korea \\ ${ }^{2}$ Department of Agricultural Biology, National Academy of Agricultural Science, RDA, Jeonju 54875, Korea
}

\section{산지별 식용 귀뚜라미의 이화학적 특성}

\author{
김은미 ${ }^{1} \cdot$ 김대현 $^{1} \cdot$ 임정호 $^{1 *} \cdot$ 장윤제 $^{1} \cdot$ 이용환 $^{1} \cdot$ 박진주 $^{1} \cdot$ 안미영 ${ }^{2}$ \\ ${ }^{1}$ 한국식품연구원, ${ }^{2}$ 농촌진흥청
}

\begin{abstract}
Insects have gained increasing attention as an alternative protein and nutrient rich food source for humans. This study was conducted to investigate the physicochemical characteristics and harmful components of edible crickets (Gryllus bimaculatus) in the 6 districts of Yeonggwang (YG), Jeongseon (JS), Wonju (WJ), Hwaseong (HS), Geochang (GC), and Chungju (CJ). The average crude protein and crude lipid contents on a dry basis were $64.34 \%$ and $16.60 \%$, respectively. The crude protein content of $C J$ was the highest $(67.40 \%)$, whereas YG $(59.42 \%)$ had the lowest content. On the other hand, the crude fat content of YG was the highest $(20.61 \%)$, whereas CJ (14.04\%) had the lowest content. The unsaturated fatty acid contents were $57.97-63.93 \mathrm{~g} / 100 \mathrm{~g}$ of the total fatty acid content in the crickets of the 6 districts. The major fatty acids of the crickets in the 6 districts were palmitic acid, oleic acid, and linoleic acid. Among the essential amino acids, valine, leucine, and lysine were the most abundant. GC had the highest total amino acids $(57.93 \mathrm{~g} / 100 \mathrm{~g})$, whereas YG $(48.65 \mathrm{~g} / 100 \mathrm{~g})$ had the lowest. Major mineral contents included potassium $(\mathrm{K}, 0.92 \sim 1.01 \mathrm{mg} / 100 \mathrm{mg})$ and phosphorus $(\mathrm{P}, 0.74 \sim 0.88 \mathrm{mg} / 100 \mathrm{mg})$. The mineral composition was fairly similar among the crickets. Crickets in the 6 districts were verified to have safe levels of residual heavy metals according to the Korea Food \& Drug Administration (KFDA) advisory levels.
\end{abstract}

Key words : Gryllus bimaculatus, cricket, edible insect, indicator components, quality

\section{서 론}

곤충은 전 세계적으로 130 만 종이 서식하며 전체 생물군 의 $70 \%$ 이상으로 다양성 측면에서 지상 최대의 생물자원이 다. 2008년 유엔식량 농업기구(FAO)가 태국 치앙마이에서 개최한 워크숍을 기점으로 곤충은 식재료부터 의약품까지 산업 전반에서 활용가치가 높아지면서 경제 발전을 이끌

*Corresponding author. E-mail : jhlim@kfri.re.kr Phone : 82-31-780-9331, Fax : 82-31-780-9333

Received 21 September 2015; Revised 23 November 2015; Accepted 25 November 2015.

Copyright (c) The Korean Society of Food Preservation. All rights reserved.
새로운 동력원으로 떠오르고 있다. 우리나라 곤충산업시장 은 2013년 현재 약 1천 600억 원 수준이며 2015년에는 3천 억 원 이상으로 증가하고 2020 년에는 1 조 원을 돌파할 것으 로 전망된다(1).

세계 20 억 명의 사람들이 1,900 여 종의 곤충을 전통식단 의 일부로 곤충을 먹고 있으며, 가장 많이 먹고 있는 곤충은 딱정벌레목(31\%), 나비목(18\%), 벌목(14\%), 메뚜기목 (13\%), 노란재목(10\%), 흰개미목(3\%), 잠자리목(3\%), 파리 목 $(2 \%)$ 이며 기타 곤충이 $5 \%$ 를 차지한다. 세계미래학회가 제시한 20년 후 유망한 10 대 미래 기술에도 곤충을 활용한 신약 개발이 포함되어 있으며 한의학에서도 예로부터 곤충 을 약재로 활용해 왔다. 허준의 <동의보감>에서는 지네, 땅강아지 등 95 종 약용 곤충의 효능이 자세히 소개되어있 
다(2-4). 외국에서는 다양한 식용곤충이 사육되고 있는데, 주로 인도, 중국, 아프리카 및 중남미 국가에서 곤충이 식용 으로 사육되고 있으며, 동시에 영양학적 측면과 안전성에 대한 다양한 연구와 식품으로써 가공에 대한 연구도 함께 진행되고 있다. 현재까지 연구 보고된 식용 곤충들은 풍뎅 이, 흰개미, 밀웜 및 귀뚜라미 등이 있으며, 가장 많이 식용 으로 알려진 곤충은 흰개미이다 $(5,6)$.

한국에서 식용곤충(edible insect)의 개념에 정확히 부합 하는 경우로 벼메뚜기, 고치, 번데기가 많이 알려져 있다(7). 귀뚜라미, 갈색거저리, 흰점박이꽃무지 및 장수풍뎅이 유 충은 식품의약품안전처로부터 한시적 식품원료로 인증을 받았으며 식용화를 위한 가공 및 유통 안정화에 대한 연구 가 지속되고 있다(8,9).

이러한 식용곤충은 식량공급의 다양성 확보와 가축 단백 질 자원의 공급에 한계성 등을 극복하기 위한 매우 중요한 대안 자원이다. 사람이 먹는 곡물로 사육하는 소, 돼지 및 닭 등은 생산 효율성이 낮아 $1 \mathrm{~kg}$ 의 고기를 생산하는데 $2 \mathrm{~kg}$ 이상의 곡물이 필요한 것으로 알려져 있다(10). 반면, 곤충은 냉온동물이라 체온을 유지하지 않아 적은 양의 사료 와 물로도 충분히 자라고 식물의 잎과 유기농 부산물을 이용하여 사육할 수 있기 때문에, 가축보다 적은비용으로 고단백질을 생산할 수 있다(11).

상업적 목적으로 한국에 도입된 쌍별귀뚜라미(Gryllus bimaculatus)는 메뚜기목(Orthoptera) 귀뚜라미과(Gryllidae) 에 속한다. 일본, 대만, 인도, 아프리카 등 아열대 지역에 분포하며, 몸빛은 흑갈색이고 앞날개 양 측면에 노란색의 별 모양 무늬가 있다(12). $15^{\circ} \mathrm{C}$ 이상의 온도 조건에서 온도 가 높아질수록 산란수가 증가하며, 산란 후 약 2주 뒤에 부화한다. 몸길이가 약 $1.7 \sim 2.1 \mathrm{~cm}$ 이고 잡식성이며 8 10월 에 출현빈도가 높은 곤충이다(13). 귀뚜라미 식용은 17세기 유럽에서 결석의 치료 및 이뇨제로 사용하기도 하였고 일본 에서는 설사, 이질 및 장티푸스를 치료하는데 사용하였으 며(14) 이외에도 면역력 증가(15), 알코올 분해 대사 촉진과 강장제로도 효과적인 원료로 연구(16) 되었다.

현재 한국에서는 귀뚜라미(Gryllus bimaculatus)를 사육 하는 농가가 늘고 있는데, 아직까지는 식용으로 사용하기 보다는 애완동물의 먹이나 낚시미끼로 사용하기 위한 수요 가 많은 것으로 알려져 있다(17). 일반적으로 귀뚜라미 사육 농가에서는 귀뚜라미 사료로 곡물사료 $80 \%$ 에 단백질원인 대두박을 $20 \%$ 혼합하여 사용하고 있으나, 확립된 사육방법 이 없어 사료 및 수분공급원 등의 사육환경 요인이 지역별 로 조금씩 다른 실정이다. 따라서 귀뚜라미의 사육환경 요 인이 귀뚜라미의 식품학적 특성에 미치는 영향에 대해 조사 하고자 하였으며, 식품원료로서의 귀뚜라미에 대한 기초자 료로 활용하고자 한다.

\section{재료 및 방법}

재 료

귀뚜라미를 전라도, 강원도, 경기도, 충청도 및 경상도 지역별로 구분하여 시료를 구입하고자 전남 영광( $\mathrm{YG})$, 강 원 정선(JS), 강원 원주(WJ), 경기 화성(HS), 경남 거창(GC) 및 충북 충주 $(\mathrm{CJ})$ 의 농장에서 크기 $2.5 \sim 3 \mathrm{~cm}$ 의 성충을 생체 로 구매하여 사용하였다. 모든 귀뚜라미 원료는 2 3회 수세 후, 탈수한 다음 심온동결고에 $1 \mathrm{~kg}$ 단위로 소포장하여 보관 하며 실험원료로 사용하였다. 분석용 시료는 동결시료를 동결건조기(FD8508, Ilshin Co., Seoul, Korea)를 이용하여 동결건조 하였으며, 이를 분쇄(40 mesh)하여 분말시료를 실험원료로 사용하였다.

\section{일반성분 및 조섬유소 분석}

산지별 귀뚜라미의 일반성분 분석은 $\mathrm{AOAC}$ 법(18)에 따 라 수분은 $105^{\circ} \mathrm{C}$ 상압가열건조법, 단백질은 Kjeltec system (Kjeltec auto sampler system 8240 analyzer, Foss Tecator, Hilleroed, Denmark), 조지방은 diethyl ether에 의한 Soxhlet 추출법, 조회분은 $550^{\circ} \mathrm{C}$ 회화법, 조섬유는 $1.25 \%$ 황산 분해 법을 이용하여 측정하였다. 귀뚜라미의 일반성분을 $100 \%$ 로 하고 이것에서 수분, 단백질, 지방, 회분 및 섬유의 함량 을 뺀 나머지를 nitrogen free extract(NFE)라고 하여 탄수화 물 함량을 나타내었다.

\section{지방산 분석}

산지별 귀뚜라미의 지방산 분석은 Folch 등(19)의 방법에 따라 2:1(v/v)로 chloroform과 methanol을 섞은 용액으로 추 출하였고, 추출된 지질은 Morrison과 Smith(20)의 방법에 준하여 전처리 후 gas chromatography(Shimadzu Co., Tokyo, Japan)를 사용하여 분석하였다. Gas chromatography 조건은 capillary column(SP-2380, film thickness $0.25 \mu \mathrm{m}$, SUPELCO Inc., Bellefonte, PA, USA)을 이용하였고 injector 온도 $260^{\circ} \mathrm{C}$, detector 온도 $270^{\circ} \mathrm{C}$, detector는 $\mathrm{FID}$ 를 사용하였다.

\section{구성 아미노산 분석}

산지별 귀뚜라미의 아미노산 분석은 각 시료 약 $1.0 \mathrm{~g}$ 을 정확히 취하여 ample에 넣고 $6 \mathrm{~N} \mathrm{HCl} 15 \mathrm{~mL}$ 를 가한 다음 $\mathrm{N}_{2}$ 로 치환하여 신속하게 밀봉하였다. 이를 $105^{\circ} \mathrm{C}$ 오븐에서 24 시간 가수분해 시킨 뒤 방냉하여 탈이온수로 $50 \mathrm{~mL}$ 정용 플라스크에 정용 후, $0.2 \mu \mathrm{m}$ membrane 필터로 여과하였다. 여액 $2 \mathrm{~mL}$ 를 취해 $25 \mathrm{~mL}$ 정용한 후, 이를 AccQ-Tag 방법 (21)으로 유도체화(AccQ-Fluor Reagent Kit, Waters corporation, Milford, MA, USA) 시키고 아미노산 분석기(pump PU-980, detector FP-920, autosampler AS-950-10, Jasco, Easton, MD, USA)를 이용하여 아미노산을 분석하였다. 이때 구성아미 노산 분석조건은 칼럼은 Nova-Pak C18(3.9×150 mm, 
Waters corporation, Milford, MA, USA), 주입 량은 $10 \mu \mathrm{L}$, 칼럼 온도는 $30^{\circ} \mathrm{C}$, 검출기는 fluorescence (Ex. $250 \mathrm{~nm}, \mathrm{Em}$. $395 \mathrm{~nm}$ ), 이동상은 $0.14 \mathrm{M}$ sodium acetate(A), 60\% acetonitrile(B)의 gradient법(21)으로 분석하였다. 이때 사용 한 시약은 특급 및 HPLC용을 사용하였으며, 아미노산 표준 물질은 amino acid standard(Sigma Chemical Co., St. Louis, $\mathrm{MO}, \mathrm{USA})$ 를 사용하였다.

\section{무기질 분석}

산지별 귀뚜라미 시료에 함유된 무기질 성분은 식품공전 의 무기질 성분 분석법과 $\mathrm{AOAC}$ 방법(18)에 따라 분석하였 고, $\mathrm{Ca}, \mathrm{Mg}, \mathrm{Mn}, \mathrm{Fe}, \mathrm{Zn}, \mathrm{Cu}$ 등의 성분을 측정하였다. 무기질 성분의 분석은 유도결합플라즈마 원자방출분광기(ICP-AES Optima 4300DV, Perkin Elmer Inc., Waltham, MA, USA)를 사용하였으며, 음이온 성분인 Cl-와 $\mathrm{SO}_{4}{ }^{2-}$ 의 정량에 이용한 이온크로마토그래프(ion chromatograph, IC)는 Dionex사 (DX-120, Dionex Co., Sunnyvale, CA, USA)의 것을 사용하 였으며 분석조건은 eluent로 $\mathrm{Na}_{2} \mathrm{CO}_{3} / \mathrm{NaHCO}_{3}$ 를 $\mathrm{AS} 14$ column과 $1.2 \mathrm{~mL} / \mathrm{min}$ 의 flow rate 그리고 conductivity detector를 사용하였다. 각 무기질의 검출 파장은 $\mathrm{Ca}$ : 393.366, P: 213.618, K: 766.491, Mg: 279.553, Mn: 257.610, $\mathrm{Fe}$ : 238.204, $\mathrm{Zn}$ : 213.856 및 $\mathrm{Cu} 324.754 \mathrm{~nm}$ 이었다.

\section{중금속 분석}

산지별 귀뚜라미의 중금속 분석은 ICP-OES(Spectro
Arcos, Spectro Analytical Instruments $\mathrm{GmbH}$, Kleve, Germany)를 이용하여 식품공전의 규정에 따라 분석하였다. 원소별 측정 파장은 $\mathrm{Pb}: 220.353, \mathrm{Cd}: 228.802, \mathrm{As}: 193.696$ 및 $\mathrm{Hg}$ : $194.227 \mathrm{~nm}$ 로 측정하였다.

\section{통계 처리}

실험결과는 SAS program(SAS Institute Inc, Cary, NC, $\mathrm{USA}$ )을 이용하여 분산분석(ANOVA)을 실시하였으며, 평 균간의 유의성 검증은 tukey test로 $\mathrm{p}<0.05$ 에서 실시하였다.

\section{결과 및 고찰}

\section{일반성분 및 조섬유소 함량}

국내 6곳에서 수집한 귀뚜라미는 영양소의 절대량 비교 를 위해 raw basis와 dry basis로 일반성분 및 조섬유소 함량 을 각각 나타내었다(Table 1). 귀뚜라미의 평균 수분함량은 $70.22 \%$ 였으며, 단백질과 지방함량이 각각 $20.04 \%$ 와 $4.35 \%$ 로 나타났다. 동결건조 귀뚜라미 분말의 경우 단백질 함량 은 충북 충주에서 $67.40 \%$ 로 가장 높았으며, 전남 영광에서 $59.42 \%$ 로 가장 낮았다. 조지방의 경우 전남 영광에서 $20.61 \%$ 로 가장 높았으며, 충북 충주지역이 $14.04 \%$ 로 가장 낮았다. 조회분의 경우 강원 원주가 $3.91 \%$ 로 가장 낮았으 며, 타지역은 5.30 5.97\%를 나타내었다. NFE값은 2.13 $2.79 \%$ 로 산지별로 유사한 함량을 나타내었다. 분석결과

Table 1. General composition of crickets from different districts

(Unit: \%)

\begin{tabular}{|c|c|c|c|c|c|c|c|}
\hline & Districts $^{1)}$ & Moisture & Crude protein & Crude fat & Crude ash & Crude fiber & $\begin{array}{l}\text { Nitrogen free extract } \\
(\mathrm{NFE})^{2)}\end{array}$ \\
\hline \multirow{7}{*}{$\begin{array}{l}\text { Raw } \\
\text { basis }\end{array}$} & YG & $70.76 \pm 0.25^{\mathrm{d} 3)}$ & $17.67 \pm 0.28^{a}$ & $6.13 \pm 0.04^{\mathrm{e}}$ & $1.78 \pm 0.02^{\mathrm{d}}$ & $2.98 \pm 0.09^{\mathrm{bcd}}$ & $0.69 \pm 0.02^{\mathrm{a}}$ \\
\hline & JS & $69.03 \pm 0.13^{\mathrm{a}}$ & $20.53 \pm 0.08^{\mathrm{d}}$ & $5.04 \pm 0.11^{\mathrm{c}}$ & $1.79 \pm 0.03^{\mathrm{d}}$ & $2.96 \pm 0.13^{\mathrm{bc}}$ & $0.67 \pm 0.00^{\mathrm{a}}$ \\
\hline & WJ & $70.29 \pm 0.10^{c}$ & $19.06 \pm 0.12^{\mathrm{b}}$ & $5.92 \pm 0.01^{\mathrm{d}}$ & $1.18 \pm 0.01^{\mathrm{a}}$ & $2.88 \pm 0.09^{b}$ & $0.74 \pm 0.04^{\mathrm{ab}}$ \\
\hline & HS & $71.33 \pm 0.12^{\mathrm{e}}$ & $19.07 \pm 0.17^{\mathrm{b}}$ & $4.21 \pm 0.01^{\mathrm{a}}$ & $1.54 \pm 0.07^{\mathrm{b}}$ & $3.05 \pm 0.04^{d}$ & $0.81 \pm 0.07^{\mathrm{b}}$ \\
\hline & GC & $70.48 \pm 0.20^{\mathrm{cd}}$ & $19.56 \pm 0.11^{\mathrm{c}}$ & $4.44 \pm 0.07^{b}$ & $1.67 \pm 0.06^{c}$ & $3.11 \pm 0.03^{\mathrm{d}}$ & $0.75 \pm 0.05^{\mathrm{ab}}$ \\
\hline & $\mathrm{CJ}$ & $69.96 \pm 0.17^{\mathrm{b}}$ & $20.51 \pm 0.23^{\mathrm{d}}$ & $4.27 \pm 0.01^{\mathrm{a}}$ & $1.78 \pm 0.01^{\mathrm{d}}$ & $2.69 \pm 0.02^{\mathrm{a}}$ & $0.80 \pm 0.06^{b}$ \\
\hline & Average & $70.22 \pm 0.33$ & $20.04 \pm 0.55$ & $4.35 \pm 0.10$ & $1.72 \pm 0.07$ & $2.90 \pm 0.23$ & $0.77 \pm 0.06$ \\
\hline \multirow{7}{*}{$\begin{array}{l}\text { Dry } \\
\text { basis }\end{array}$} & YG & $1.69 \pm 0.12^{\mathrm{c}}$ & $59.42 \pm 0.10^{\mathrm{a}}$ & $20.61 \pm 0.34^{\mathrm{e}}$ & $5.97 \pm 0.01^{\mathrm{d}}$ & $10.01 \pm 0.18^{c}$ & $2.31 \pm 0.07^{\mathrm{ab}}$ \\
\hline & JS & $1.38 \pm 0.06^{\mathrm{ab}}$ & $65.35 \pm 0.05^{c}$ & $16.03 \pm 0.40^{c}$ & $5.69 \pm 0.06^{c}$ & $9.43 \pm 0.37^{b}$ & $2.13 \pm 0.01^{\mathrm{a}}$ \\
\hline & WJ & $1.42 \pm 0.05^{\mathrm{b}}$ & $63.04 \pm 0.32^{\mathrm{b}}$ & $19.64 \pm 0.12^{\mathrm{d}}$ & $3.91 \pm 0.00^{\mathrm{a}}$ & $9.55 \pm 0.27^{b}$ & $2.45 \pm 0.12^{\mathrm{bc}}$ \\
\hline & HS & $1.43 \pm 0.01^{\mathrm{b}}$ & $65.54 \pm 0.29^{c}$ & $14.46 \pm 0.07^{b}$ & $5.30 \pm 0.23^{\mathrm{c}}$ & $10.49 \pm 0.19^{d}$ & $2.79 \pm 0.26^{\mathrm{d}}$ \\
\hline & GC & $1.44 \pm 0.02^{\mathrm{b}}$ & $65.31 \pm 0.09^{c}$ & $14.82 \pm 0.12^{b}$ & $5.47 \pm 0.06^{\mathrm{b}}$ & $10.38 \pm 0.02^{\mathrm{cd}}$ & $2.61 \pm 0.09^{\text {cd }}$ \\
\hline & $\mathrm{CJ}$ & $1.29 \pm 0.09^{\mathrm{a}}$ & $67.40 \pm 0.44^{\mathrm{d}}$ & $14.04 \pm 0.09^{\mathrm{a}}$ & $5.84 \pm 0.01^{\mathrm{cd}}$ & $8.83 \pm 0.08^{\mathrm{a}}$ & $2.62 \pm 0.20^{\mathrm{cd}}$ \\
\hline & Average & $1.44 \pm 0.14$ & $64.34 \pm 2.62$ & $16.60 \pm 2.66$ & $5.36 \pm 0.71$ & $9.78 \pm 0.62$ & $2.48 \pm 0.26$ \\
\hline
\end{tabular}

${ }^{1)}$ YG, Yeong-gwang; JS, Jeong-seon; WJ, Won-ju; HS, Hwa-seong; GC, Geo-chang; CJ, Chung-ju.

${ }^{2)} \mathrm{NFE}=100$-(Moisture+Crude protein+Crude fat+Crude Ash + Crude fiber).

${ }^{3)}$ Values are mean $\pm \mathrm{SD}(\mathrm{n}=3)$. Means with different letters within a same column are significantly different at $\mathrm{p}<0.05$. 
산지별 통계적 유의차는 있었지만(p<0.05), 실제 함량의 차 이는 크게 나타나지 않았다. 이는 식용 풍뎅이나 콩박각시 를 분석한 결과와 일치하였다(22,23). 본 연구를 포함하여 식용 풍뎅이나 콩박각시 모두 $65 \%$ 내외의 단백질 함량을 나타내어 식용 곤충은 고단백질 식품으로서 고기의 대용으 로 사용이 가능함을 보여주었다. 섬유소의 함량은 8.83 $10.49 \%$ 수준으로 매우 높았는데 이는 식용곤충의 딱딱한 큐티클 층에 기인하는 것으로 이의 가공 방법에 따라 기능 성 식품의 원료로 이용 가능성이 충분함을 나타낸다. 실제 로 일부 아프리카에서는 흰개미를 이용한 의약품 생산에 큐티클 층을 이용하는 것으로 알려져 있다(24).

\section{지방산 함량}

산지별 귀뚜라미의 지방산 함량을 조사한 결과 palmitic $\operatorname{acid(C16:0),~oleic~} \operatorname{acid}(18: 1)$ 및 linoleic $\operatorname{acid}(18: 2)$ 함량이 높 게 나타났다(Table 2). 이는 Hutchins과 Martin(25), Grapes 등(26)과 Kim과 Jung(27)이 조사한 연구와 비슷한 경향을 나타내었다. 강원 원주, 경기 화성 및 전남 영광에서 linoleic acid 함량은 각각 $37.85,34.46$ 및 $34.45 \mathrm{~g} / 100 \mathrm{~g}$ 으로 높았으 며, oleic acid 함량은 22.73, 21.66 및 $21.29 \mathrm{~g} / 100 \mathrm{~g}$ 으로 유사한 함량을 나타내었고, palmitic acid 함량은 23.72, 23.37 및 $21.09 \mathrm{~g} / 100 \mathrm{~g}$ 을 나타내었다. 충북 충주, 강원 정선, 경남 거창에서는 linoleic acid 함량이 30.54, 29.86 및 29.74 $\mathrm{g} / 100 \mathrm{~g}$ 을 나타내었고, oleic acid 함량은 24.46, 23.50 및 $23.03 \mathrm{~g} / 100 \mathrm{~g}$ 으로 유사하였으며, palmitic acid 함량은 $22.67,24.00$ 및 $24.19 \mathrm{~g} / 100 \mathrm{~g}$ 을 나타내었다. 전체 지방산
중 불포화 지방산 함량의 비율은 57.97 63.93\%로 포화지방 산 보다 높은 함량을 나타내었고, 강원 원주가 $63.93 \%$ 로 가장 높은 함량을 나타내었다. 경남 거창과 충북 충주에서 는 myristic acid가 나타나지 않았으며, 강원 원주에서는 myristic acid와 eicosenoic acid가 발견되지 않았다. 경기 화성에서는 linolenic acid가 발견되지 않았다.

따라서, 귀뚜라미의 식용화 시 oleic acid 및 linoleic acid 와 같은 불포화 지방산이 풍부함으로 이용가치가 높다고 할 수 있다.

\section{구성 아미노산 함량}

산지별 귀뚜라미의 아미노산 함량은 Table 3에 나타내었 으며, threonine 외 16종의 아미노산이 확인되었다. 총 아미 노산 함량은 경남 거창이 $57.93 \mathrm{~g} / 100 \mathrm{~g}$ 으로 가장 높았으며, 전남 영광이 $48.65 \mathrm{~g} / 100 \mathrm{~g}$ 으로 가장 낮았다. 필수 아미노산 함량 중 valine, leucine 및 lysine 함량이 높았으며, valine 함량은 전남 영광 지역이 $2.92 \mathrm{~g} / 100 \mathrm{~g}$ 으로 타지역 $3.97 \sim 4.47$ $\mathrm{g} / 100 \mathrm{~g}$ 보다 낮은 함량을 나타내었다. 필수 아미노산의 함 량은 $18.01 \sim 22.80 \mathrm{~g} / 100 \mathrm{~g}$ 으로 산지별 큰 차이가 없었다. 비필수아미노산 중 감칠맛의 대표성분으로 알려진 glutamic acid 함량이 경남 거창에서 $6.91 \mathrm{~g} / 100 \mathrm{~g}$ 으로 가장 높게 나타났으며, 충북 충주 $6.00 \mathrm{~g} / 100 \mathrm{~g}$ 으로 가장 낮게 나타났으나 큰 차이는 나타나지 않았다. 필수 아미노산 중 높은 함량을 나타낸 val, leu, ile 등의 branched chain amino $\mathrm{acid}$ 는 운동이나 보디빌딩을 하는 사람들의 근육량 증가에 특히 유리할 것으로 생각되며(28) arginine 함량도 높아 음

Table 2. Fatty acid contents of crickets from different districts

(Unit: g/100 g samples)

\begin{tabular}{|c|c|c|c|c|c|c|}
\hline \multirow{2}{*}{ Fatty acid } & \multicolumn{6}{|c|}{ Districts $^{1)}$} \\
\hline & YG & JS & WJ & HS & GC & $\mathrm{CJ}$ \\
\hline \multicolumn{7}{|l|}{ Saturated fatty acid (SFA) } \\
\hline C14:0 (Myristic acid) & $1.74 \pm 0.05^{2)}$ & $0.42 \pm 0.59$ & 3) & $0.36 \pm 0.51$ & - & - \\
\hline C16:0 (Palmitic acid) & $21.09 \pm 0.28$ & $24.00 \pm 1.42$ & $23.72 \pm 0.54$ & $23.37 \pm 0.28$ & $24.19 \pm 0.09$ & $22.67 \pm 0.73$ \\
\hline C18:0 (Stearic acid) & $9.29 \pm 0.13$ & $7.89 \pm 0.32$ & $7.91 \pm 0.09$ & $8.93 \pm 0.09$ & $7.79 \pm 0.08$ & $9.97 \pm 0.34$ \\
\hline Total SFA & $32.12 \pm 0.13$ & $32.31 \pm 0.71$ & $31.62 \pm 0.19$ & $32.66 \pm 0.16$ & $31.99 \pm 0.10$ & $32.64 \pm 0.62$ \\
\hline \multicolumn{7}{|l|}{ Unsaturated fatty acid (USFA) } \\
\hline C16:1 (Palmitoleic acid) & $1.03 \pm 0.03$ & $2.53 \pm 0.19$ & $1.37 \pm 0.00$ & $1.26 \pm 0.03$ & $2.69 \pm 0.10$ & $1.89 \pm 0.04$ \\
\hline C18:1n9c (Oleic acid) & $21.29 \pm 0.19$ & $23.50 \pm 1.40$ & $22.73 \pm 0.53$ & $21.66 \pm 0.28$ & $23.03 \pm 0.01$ & $24.46 \pm 0.92$ \\
\hline C18:2n6c (Linoleic acid) & $34.45 \pm 0.40$ & $29.86 \pm 1.75$ & $37.85 \pm 0.56$ & $34.46 \pm 0.38$ & $29.74 \pm 0.39$ & $30.54 \pm 0.74$ \\
\hline C18:3n3 (Linolenic acid) & $1.48 \pm 0.05$ & $0.99 \pm 0.39$ & $1.98 \pm 0.02$ & - & $1.43 \pm 0.05$ & $0.72 \pm 1.02$ \\
\hline C20:1 (cis-9-eicosenoic acid) & $0.84 \pm 0.07$ & $1.23 \pm 0.05$ & - & $1.27 \pm 0.18$ & $1.08 \pm 0.04$ & $1.57 \pm 0.12$ \\
\hline Total USFA & $59.99 \pm 0.15$ & $58.48 \pm 0.78$ & $63.93 \pm 0.21$ & $59.70 \pm 0.29$ & $57.97 \pm 0.06$ & $59.81 \pm 0.36$ \\
\hline USFA/SFA & 1.87 & 1.81 & 2.02 & 1.83 & 1.81 & 1.83 \\
\hline
\end{tabular}

\footnotetext{
${ }^{1)}$ YG, Yeong-gwang; JS, Jeong-seon; WJ, Won-ju; HS, Hwa-seong; GC, Geo-chang; CJ, Chung-ju.

${ }^{2)}$ Values are mean \pm SD $(\mathrm{n}=3)$.

${ }^{3)}$ Not detected.
} 
주 후 숙취해소 효과도 있을 것으로 추정되고(29), methionine 은 혈중 콜레스테롤 수준 저하와 간의 지방 침착 해소효과 등의 효과가 있을 것으로 사료된다(30).

따라서, 산지별 귀뚜라미는 17 종의 아미노산을 골고루 함유하고 있어 영양학적인 측면에서 우수한 식품원으로 이용할 수 있을 것으로 판단된다.

Table 3. Amino acid contents of crickets from different districts

\begin{tabular}{|c|c|c|c|c|c|c|}
\hline \multirow{3}{*}{ Amino acid } & \multicolumn{6}{|c|}{ (Unit: $\mathrm{g} / 100 \mathrm{~g}$ samples } \\
\hline & \multicolumn{6}{|c|}{ Districts $^{1)}$} \\
\hline & YG & JS & WJ & $\mathrm{HS}$ & GC & $\mathrm{CJ}$ \\
\hline \multicolumn{7}{|c|}{ Essential amino acid (EAA) } \\
\hline Threonine & 2.16 & 2.42 & 2.26 & 2.37 & 2.42 & 2.15 \\
\hline Valine & 2.92 & 4.47 & 3.97 & 4.36 & 4.28 & 4.03 \\
\hline Isoleucine & 1.98 & 2.37 & 2.28 & 2.32 & 2.52 & 2.06 \\
\hline Leucine & 3.82 & 4.67 & 4.23 & 4.48 & 4.75 & 4.04 \\
\hline Phenylalanine & 1.88 & 2.22 & 2.13 & 2.05 & 2.43 & 1.89 \\
\hline Lysine & 3.14 & 3.63 & 3.52 & 3.69 & 3.83 & 3.18 \\
\hline Histidine & 1.28 & 1.53 & 1.42 & 1.48 & 1.60 & 1.34 \\
\hline Methionine & 0.83 & 0.99 & 0.92 & 0.97 & 0.97 & 0.89 \\
\hline Total EAA & 18.01 & 22.30 & 20.73 & 21.72 & 22.80 & 19.58 \\
\hline \multicolumn{7}{|c|}{ Non-essential amino acid (NEAA) } \\
\hline Aspartic acid & 4.15 & 5.65 & 4.91 & 5.03 & 5.67 & 4.63 \\
\hline Serine & 2.34 & 3.42 & 2.91 & 2.98 & 3.39 & 2.67 \\
\hline Glutamic acid & 6.30 & 6.75 & 6.16 & 6.74 & 6.91 & 6.00 \\
\hline Glycine & 2.80 & 3.11 & 2.90 & 3.25 & 3.08 & 2.95 \\
\hline Alanine & 5.00 & 5.40 & 4.96 & 5.48 & 5.13 & 5.11 \\
\hline Tyrosine & 3.00 & 2.98 & 2.94 & 2.82 & 3.04 & 2.81 \\
\hline Arginine & 3.49 & 3.98 & 3.77 & 3.95 & 4.02 & 3.53 \\
\hline Cystine & 0.53 & 0.56 & 0.49 & 0.54 & 0.55 & 0.51 \\
\hline Proline & 3.03 & 3.43 & 3.20 & 3.54 & 3.34 & 3.12 \\
\hline Total NEAA & 30.64 & 35.28 & 32.24 & 34.33 & 35.13 & 31.33 \\
\hline $\mathrm{TAA}^{2)}$ & 48.65 & 57.58 & 52.97 & 56.05 & 57.93 & 50.91 \\
\hline
\end{tabular}

${ }^{1)}$ YG, Yeong-gwang; JS, Jeong-seon; WJ, Won-ju; HS, Hwa-seong; GC, Geo-chang; $\mathrm{CJ}$, Chung-ju.

${ }^{2)}$ TAA, total amino acid.

\section{무기질 함량}

귀뚜라미 원료의 무기질 함량을 분석한 결과 평균적으로 칼륨과 인의 함량이 $0.92 ~ 1.01 \mathrm{mg} / 100 \mathrm{mg}$ 와 $0.74 \sim 0.88$ $\mathrm{mg} / 100 \mathrm{mg}$ 로 높게 나타났다(Table 4). 칼숨의 함량은 전남 영광에서 $0.30 \mathrm{mg} / 100 \mathrm{mg}$ 으로 경기 화성 $0.17 \mathrm{mg} / 100 \mathrm{mg}$ 보 다 높게 나타났다. 철의 경우 전남 영광에서 $103 \mathrm{ppm}$ 으로 타 지역의 44 82 ppm보다 높은 값을 나타내었다. 전체적으 로 망간과 구리의 함량은 낮으나, 항산화 효소의 필수적인 금속이온인 아연은 170 299 ppm으로 높은 함량을 갖는
것으로 조사되었다. 아연은 약 300 여 종의 효소에 필요한 성분으로 단백질 합성, 면역 등 생명활동의 기본으로 작용 하는 것이 많고 $\mathrm{DNA}$ 의 회복과 활성산소 제거에 작용하는 효소에도 관여하므로 노화와 암의 예방에 중요한 성분으로 알려져 있다(31).

Table 4. Mineral contents of crickets from different districts

\begin{tabular}{cccccccc}
\hline \multirow{2}{*}{$\begin{array}{c}\text { Inorganic } \\
\text { elements }\end{array}$} & Unit & \multicolumn{7}{c}{ Districts $^{\text {1) }}$} \\
\cline { 3 - 8 } & & YG & JS & WJ & HS & GC & CJ \\
\hline $\mathrm{Ca}$ & & 0.30 & 0.24 & 0.18 & 0.17 & 0.25 & 0.25 \\
$\mathrm{P}$ & $\mathrm{mg} /$ & 0.82 & 0.85 & 0.77 & 0.79 & 0.88 & 0.74 \\
$\mathrm{~K}$ & $100 \mathrm{mg}$ & 0.94 & 1.01 & 0.92 & 0.99 & 0.96 & 0.95 \\
$\mathrm{Mg}$ & & 0.12 & 0.10 & 0.08 & 0.09 & 0.11 & 0.09 \\
\hline $\mathrm{Mn}$ & & 57 & 69 & 43 & 33 & 67 & 49 \\
$\mathrm{Fe}$ & & 103 & 56 & 64 & 44 & 54 & 82 \\
$\mathrm{Zn}$ & $\mathrm{ppm}$ & 248 & 299 & 171 & 170 & 283 & 284 \\
$\mathrm{Cu}$ & & 14 & 11 & 9 & 10 & 11 & 12 \\
\hline
\end{tabular}

${ }^{1)}$ YG, Yeong-gwang; JS, Jeong-seon; WJ, Won-ju; HS, Hwa-seong; GC, Geo-chang; CJ, Chung-ju.

\section{중금속 함량}

귀뚜라미 원료의 중금속인 납, 카드뮴, 비소 및 수은함량 을 분석한 결과 경남 거창에서는 $0.26 \mathrm{ppb}$ 의 납 성분이 검출되었으며 전남 영광, 강원 정선, 경남 거창에서는 카드 뮴이 각각 $0.07,0.03,0.03 \mathrm{ppb}$ 가 검출되었다(Table 6). 수은 은 모든 지역에서 검출되었으며 비소는 모든 지역에서 검출 되지 않았다. 이는 사육지역의 환경적 요인(지하수 등)에 의한 결과로 해석된다. 중금속은 체내 축적성이 강하며 장 기간 축적 시 급·만성 질환의 건강장해를 일으킬 수 있기 때문에(32), 중금속 허용기준치가 규정되어 있다. 따라서, 식품으로 사육시 표준화된 사육방법의 설정이 요구된다. 산지별 귀뚜라미의 경우 CODEX 쌀 카드뮴 허용치 : 0.4 $\mathrm{ppm}$ 이하(33), 식약처고시 $0.2 \mathrm{ppm}$ 이하(34)에 미달되는 함 량으로 식품원료로서 문제가 없는 수준이었다. 또한, 산지 별 귀뚜라미 시료의 수은함량은 1.00 3.30 ppb로 나타났으

Table 5. Heavy metal contents of crickets from different districts

\begin{tabular}{|c|c|c|c|c|c|c|}
\hline \multirow{3}{*}{ Elements } & \multicolumn{6}{|c|}{ (Unit: ppb) } \\
\hline & \multicolumn{6}{|c|}{ Districts ${ }^{1)}$} \\
\hline & YG & JS & WJ & HS & $\mathrm{GC}$ & $\mathrm{CJ}$ \\
\hline $\mathrm{Pb}$ & $\mathrm{ND}$ & $\mathrm{ND}$ & ND & $\mathrm{ND}$ & 0.26 & $\mathrm{ND}$ \\
\hline $\mathrm{Cd}$ & 0.07 & 0.03 & ND & ND & 0.03 & $\mathrm{ND}$ \\
\hline As & $\mathrm{ND}$ & ND & $\mathrm{ND}$ & ND & ND & ND \\
\hline $\mathrm{Hg}$ & 3.30 & 1.50 & 1.50 & 1.10 & 1.30 & 1.00 \\
\hline
\end{tabular}

${ }^{1)}$ YG, Yeong-gwang; JS, Jeong-seon; WJ, Won-ju, HS, Hwa-seong; GC, Geo-chang; CJ, Chung-ju. 
나, 식품공전의 수산물에 대한 수은 기준인 $0.5 \mathrm{ppm}$ 이하 (34)와 비교할 때 $1 / 100$ 수준 이하인 것으로 나타나 산지별 귀뚜라미 모두 식품원료로서 문제가 없음을 확인하였다.

\section{요 약}

본 연구는 국내에서 사육되고 있는 식용 귀뚜라미의 산 지별 이화학적 특성에 대한 조사를 하였다. 산지별 귀뚜라 미의 조단백과 조지방 함량은 각각 17.67 20.53\%와 4.21 6.13\%로 나타났다. 산지별 동결건조 귀뚜라미의 조단 백과 조지방 함량은 각각 $59.42 ~ 67.40 \%$ 와 14.04 20.61\%로 육고기 보다 높은 단백질 함량을 나타내었다. 전남 영광과 강원 원주의 조지방 함량이 20.61 및 $19.64 \%$ 로 타지역 14.04 16.03\%보다 높게 나타났다. 산지별 통계적 유의차는 있었지만(p<0.05), 실제 함량의 차이는 크게 나타나지 않았 다. 지방산의 경우 palmitic acid, oleic acid, linoleic acid가 각각 $20 \mathrm{~g} / 100 \mathrm{~g}$ 이상의 높은 함량을 나타내었다. 특히 linoleic acid 함량이 강원 원주에서 $37.85 \mathrm{~g} / 100 \mathrm{~g}$ 으로 높은 함량을 나타내었으며, 경남 거창이 $29.74 \mathrm{~g} / 100 \mathrm{~g}$ 으로 낮은 함량을 나타내었다. 필수아미노산과 비필수아미노산이 각 각 $18.01 \sim 22.80 \mathrm{~g} / 100 \mathrm{~g}$ 과 $30.64 \sim 35.28 \mathrm{~g} / 100 \mathrm{~g}$ 을 나타내었 다. 필수 아미노산 중 valine, leucine, lysine 함량이 높았다. Valine의 함량은 전남 영광이 $2.92 \mathrm{~g} / 100 \mathrm{~g}$ 으로 타지역 $3.97 \sim 4.47 \mathrm{~g} / 100 \mathrm{~g}$ 보다 낮은 함량을 나타내었고, glutamic acid 함량은 경남 거창이 $6.91 \mathrm{~g} / 100 \mathrm{~g}$ 으로 가장 높은 함량을 나타내었다. 무기질 함량은 칼륨 및 인의 함량이 0.92 1.01 $\mathrm{mg} / 100 \mathrm{mg}$ 및 $0.74 \sim 0.88 \mathrm{mg} / 100 \mathrm{mg}$ 으로 높게 나타났다. 전체적으로 망간과 구리 함량은 낮으나, 아연은 강원 정선 및 경기 화성이 299 및 $170 \mathrm{ppm}$ 으로 높게 나타났다. 중금속 함량은 납이 경남 거창지역에서만 $0.26 \mathrm{ppb}$ 가 검출 되었으 며, 타지역에서는 검출되지 않았다. 카드뭄은 전남 영광, 강원 정선 및 경남 거창에서 각각 $0.07,0.03$ 및 $0.03 \mathrm{ppb}$ 가 검출 되었으며, 타지역에서는 검출되지 않았다. 수은 함량 은 충북 충주 및 전남 영광에서 1.00 및 $3.30 \mathrm{ppb}$ 의 함량을 나타내었다. 발견된 중금속은 $\mathrm{CODEX}$ 와 식품공전의 중금 속 허용기준에 극히 미달되는 함량으로 나타나 식품원료로 서 문제가 없음을 확인하였다.

\section{감사의 글}

본 연구는 농촌진흥청 국책과제(PJ009827)에 의해 이루 어진 것으로 이에 감사드립니다.

\section{References}

1. Rural development administration (2014) Edible insects and cuisine. RDA, Jeonju, Korea, p 6

2. Srinroch C, Srisomsap C, Chokchaichamnankit D, Punyarit P, Phiriyangkul P (2015) Identification of novel allergen in edible insect, Gryllus bimaculatus and its cross-reactivity with Macrobrachium spp. allergens. Food Chem, 184, 160-166

3. Caparros Megido R, Alabi T, Nieus C, Blecker C, Danthine S, Bogaert J, Haubruge E, Francis F (2015) Optimisation of a cheap and residential small-scale production of edible crickets with local by products as an alternative protein rich human food source in Ratanakiri province, Cambodia. J Sci Food Agric, 10.1002/jsfa.7133.

4. Premalatha M, Abbasi T, Abbasi T, Abbasi S (2011) Energy-efficient food production to reduce global warming and ecodegradation : the use of edible insects. Renew Sust Energ Rev, 15, 4357-4360

5. Korea FAO Association (2014) World Food, Agriculture \& Fisheries. KFAO, Gyeonggi, Korea, 603, 98-103

6. Anankware PJ, Fening KO, Osekre E, Obeng-Ofori D (2015) Insect as food and feed. Int J Agric Res Rev, 3, 143-151

7. Chung MY, Lee JY, Lee JC, Park KS, Jeong JP, Hwang JS, Goo TW, Yun EY (2014) Establishment of self-specification and shelf-life by standardization of manufacturing process for lyophilized Tenebrio molitor larvae. J Seric Entomol Sci, 52, 73-78

8. Hwang SY, Choi SK (2015) Quality characteristics of muffins containing mealworm (Tenebrio molitor). Korean J Cul Res, 21, 104-115

9. Kwon EY, Yoo JM, Yoon YI, Hwang JS, Goo TW, Kim MA, Choi YC, Yun EY (2013) Pre-treatment of the white-spotted flower chafer (Protaetia brevitarsis) as an ingredient for novel foods. J Korean Soc Food Sci Nutr, 42, 397-402

10. Van Broekhoven S, Oonincx DG, van Huis A, van Loon JJ (2015) Growth performance and feed conversion efficiency of three edible mealworm species (Coleoptera: Tenebrionidae) on diets composed of organic by-products. J Insect Physiol, 73, 1-10

11. Van Huis A (2013) Potential of insects as food and feed in assuring food security. Annu Rev Entomol, 58, 563-583

12. Lee EN, Kwon OS (2013) The effect of invasive cricket species, Gryllus bimaculatus on the survival of Korean cricket species, Teleogryllus emma. Korean J Limnol, 46, 67-74

13. Kim EM, Lim JH, Chang YJ, An SH, Ahn MY (2015) 
Changes in the quality characteristics of cricket (Gryllus bimaculatus) under various processing conditions. Korean J Food Preserv, 22, 218-224

14. Park KT (2001) Insect resources. World science publishing company, Seoul, Korea, p 202

15. Seo DH, Hwang SY, Han JH, Koh SK, Kim IS, Ryu KS, Yun CY (2004) Immune-enhancing activity screening on extracts from two crickets, Gryllus bimaculatus and Teleogryllus emma. Entomol Res, 34, 207-211

16. Kim MA, Hwang JS, Yun EY, Kang PD (2014) Edible \& medicinal insects. RDA interrobang, Rural Development Administration, Korea, 119, 1-20

17. Park JH, Jung CE (2013) Current status and prospects of animal feed insect industry. Korean J Soil Zoology, 17, 9-13

18. AOAC (1990) Official methods of analysis. Association of official analytical chemists, Washington DC, p 17, 37,440

19. Folch J, Lees M, Stanley GHS (1957) A simple method for the isolation and purification of total lipids from animal tissues. J Biol Chem, 226, 497-509

20. Morrison WR, Smith LM (1964) Preparation of fatty acid methyl esters and dimethylacetals from lipids with boron fluoride-methanol. J Lipid Res, 5, 600-608

21. Waters Corporation (1993) Waters AccQ-Tag amino acid analysis system operator's manual number 154-02TP. Milford, MA, USA

22. Yang Q, Liu S, Sun J, Yu L, Zhang C, Bi J, Yang Z (2014) Nutritional composition and protein quality of the edible beetle Holotrichia parallela. J Insect Sci, 14, 1-4

23. Xia Z, Chen JH, Wu SJ (2013) Hypolipidemic activity of the chitooligosaccharides from Clanis bilineata (Lepidoptera), an edible insect. Int J Biol Marcromol, 59, 96-98
24. Costa-Neto Em (2005) Entomotherapy, or the medicinal use of insects. J Ethnobiol, 25, 93-114

25. Hutchins R F.N, Martin MM (1968) The lipids of the common house cricket, Acheta domesticus L. I Lipid classes and fatty acid distribution. Lipids, 3, 250-255

26. Grapes M, Whiting P, Dinan L, (1989) Fatty acid and lipid analysis of the house cricket, Acheta domesticus. Insect Biochem, 19, 767-774

27. Kim HS, Jung CU (2013) Nutritional characteristics of edible insects as potential food materials. Korean J Apiculture, 28, 1-8

28. Lee JH, Chae JS, Han KH (2005) Nutritional assessment and management in liver cirrhosis. Korean J Hepatol, 11, 97-105

29. Lee JH, Kim NK, Lee DY, Lee CH (1999) Protective effect of selected amino acids and food extracts on ethanol toxicity decrement in rat liver. Korean J Food Sci Techonol, 31, 802-808

30. Mitchell JR, Jollow DJ, Potter WZ, Gillette JR, Brodie BB (1973) Acetaminophen-induced hepatic necrosis IV Protective role of glutathion. J Pharmacol Exp Ther, 187, 211-217

31. Hambidge M (2000) Human zinc deficiency. J Nutr, 130, 1344s-1349s

32. Kim SD, Jung SO, Kim BS, Yun ES, Chang MS (2010) The content of heavy metals in herbal pills used as general processed food and risk assessment of heavy metal intakes. J Korean Soc Food Sci Nutr, 39, 1038-1048

33. Codex Alimentarius Commission (2010) Codex general standard for contaminants and toxins in food and feed. FDA, US, Codex stan 193-1995, p 27

34. Korea Food and Drug Administration (KFDA) (2006) KFDA Notification No. 2006-55, KFDA, Osong, Korea, p 1-5 